\title{
Environmental Factors Associated with Pneumonia in Children Under-Five in Nduga District, Papua
}

\author{
Yulianda Yeimo'), Isna Qadrijati²), Bhisma Murti') \\ ${ }^{1)}$ Masters Program in Public Health, Universitas Sebelas Maret \\ ${ }^{2)}$ Faculty of Medicine, Universitas Sebelas Maret
}

\begin{abstract}
Background: Pneumonia is an inflammatory condition of the lung affecting primarily the small air sacs known as alveoli. In 2016 UNICEF had reported that pneumonia remains the leading infectious cause of death among children under five, killing approximately 2,400 children a day. Mortality due to childhood pneumonia is strongly associated to poverty, lack of safe water and sanitation, indoor air pollution and absence of basic immunization. This study aimed to determine the environmental factors associated with pneumonia in children under-five in Nduga, Papua, Indonesia.

Subjects and Method: This was an analytic observational study with case-control design. This study was conducted in Yigi and Mbua Sub-districts, Nduga District, Papua, Indonesia, from December 2017 to February 2018. A sample of 184 children under-five consisting of 88 children with pneumonia (case) and 96 children without pneumonia (control), was selected for this study by fixed disease sampling. The independent variables were BCG immunization status, family income, indoor household air pollution, and environmental sanitation. The dependent variable was pneumonia. Data were collected by questionnaire and medical record. The data were analyzed by a multiple logistic regression.

Results: The risk of pneumonia in children under-five increased by absence of BCG immunization $(\mathrm{OR}=6.15 ; 95 \% \mathrm{CI}=2.78$ to $13.61 ; \mathrm{p}<0.001)$, poor indoor household air pollution $(\mathrm{OR}=5.68 ; 95 \%$ $\mathrm{CI}=2.63$ to $12.26 ; \mathrm{p}<0.001)$, and poor sanitation $(\mathrm{OR}=5.06 ; 95 \% \mathrm{CI}=2.16$ to $11.83 ; \mathrm{p}<0.001)$. The risk of pneumonia in children under-five decreased by higher family income $(\mathrm{OR}=0.30 ; 95 \% \mathrm{CI}=$ 0.13 to $0.70 ; \mathrm{p}=0.005$ ).

Conclusion: Pneumonia in children under five is associated with indoor household air pollution, poor sanitation, absence BCG immunization, and lower family income.
\end{abstract}

Keywords: pneumonia, indoor pollution, sanitation, BCG immunization, family income

\section{Correspondence:}

Yulianda Yeimo. Nduga District Health Office, Jl. Kesehatan, Kabupaten Nduga, Papua. Email: yulianda.yeimo@gmail.com. Mobile: 082198811311.

\section{BACKGROUND}

Pneumonia is an inflammation of the lower respiratory tract caused by various microorganisms ie bacteria, viruses, fungi, and protozoa. The most common causes of bacterial pneumonia in children are group B Streptococcus and gram-negative enteric bacteria. The respiratory syncytial virus is the most common virus cause of pneumonia in children aged four months to five years (Kliegman, 2016).
Pneumonia is the leading infectious that can kill children under-five in the world, but lack of attention to this disease so that pneumonia is also called "the forgotten killer of children" and the magnitude of the death of this pneumonia referred to as "forgotten pandemic" (World Health Organization and The United Nations Children's Fund, 2006; Kemenkes RI, 2012). 
Journal of Epidemiology and Public Health (2018), 3(3): 307-311

https://doi.org/10.26911/jepublichealth.2018.03.03.01

Pneumonia has killed 922,000 infants in worldwide. It was higher than diarrhea $(526,000)$, sepsis $(413,000)$, malaria (306,000), pertussis, tetanus, and meningitis $(207,000)$, and HIV (87,000). Indonesia was ranked 8th with total deaths due to pneumonia of 22,000 children (World Health Organization and The United Nations Children's Fund, 2006).

Papua Province in 2012 has estimated the number of pneumonia cases in infants as many as 10198 children under-five and only 1,057 children under-five who successfully handled by health personnel.

There are many factors that can cause pneumonia. Rylance et al., (2015) suggest that exposure to household air pollution is the cause of the 4 million deaths caused by respiratory infections, chronic lung disease, cancer, and cardiovascular disease.

Environmental factors such as indoor air pollution and sanitation are important risk factors for pneumonia, this will be examined closely related to traditional house Papua which is usually called Honai. Honai is a traditional house made from wood with a conical roof of straw or reeds.

Honai was built narrow or small, not windowed, and had a wood stove in the middle which aims to withstand the cold mountain temperatures. this condition becomes very dangerous for children's health and can increase the risk of pneumonia.

\section{SUBJECTS AND METHOD}

This was an analytic observational study with case-control design. This study was conducted in Yigi and Mbua Sub-districts, Nduga District, Papua, Indonesia, from December 2017 to February 2018.

A sample of 184 children under-five consisting of 88 children with pneumonia (case) and 96 children without pneumonia (control), was selected for this study by fixed disease sampling.

The exclusion criteria were upper respiratory tract infection, pneumonia with pertussis, and have a family member with tuberculosis diagnosed

The independent variables were BCG immunization status, family income, indoor household air pollution, and environmental sanitation. The dependent variable was pneumonia. Data were collected by questionnaire and medical record. The data were analyzed by a multiple logistic regression.

\section{RESULTS}

The risk of pneumonia in children underfive increased six times by absence of BCG immunization $(\mathrm{OR}=6.15 ; 95 \% \mathrm{CI}=2.78$ to 13.61; $\mathrm{p}<0.001)$. Poor indoor household air pollution increased the risk of pneumonia in children by 5.68 times than good indoor household air pollution $(\mathrm{OR}=5.68 ; 95 \%$ $\mathrm{CI}=2.63$ to $12.26 ; \mathrm{p}<0.001)$.

Table 1. The results of a multiple logistic regression analysis on environmental factors associated with pneumonia in children under five.

\begin{tabular}{lllll}
\hline \multirow{2}{*}{ Independent Variables } & \multirow{2}{*}{ OR } & \multicolumn{2}{c}{ 95\% CI } & \multirow{2}{*}{ p } \\
\cline { 3 - 4 } & & Lower limit & Upper limit & \\
\hline Absence of BCG immunization & 6.15 & 2.78 & 13.61 & $<0.001$ \\
Poor indoor household air pollution & 5.68 & 2.63 & 12.26 & $<0.001$ \\
Poor sanitation & 5.06 & 2.16 & 11.83 & $<0.001$ \\
higher family income & 0.31 & 0.13 & 0.70 & 0.005 \\
N observation $=184$ & & & & \\
Nagelkerke $\mathrm{R}^{2}=49,7 \%$ & & & & \\
Log likelihood $=-84.53$ & & & & \\
p $<0.001$ & & & & \\
\hline
\end{tabular}


Poor sanitation in household environment increased the risk of pneumonia by 5.06 times than goos sanitation $(\mathrm{OR}=5.06$; 95\% CI= 2.16 to 11.83 ; $<<0.001)$. Higher family income decreased the risk of pneumonia in children under-five by 0.30 times than lower family income and statistically significant $(\mathrm{OR}=0.30 ; 95 \% \mathrm{CI}=0.13$ to $0.70 ; p=0.005$.

\section{DISCUSSION}

Honai is a traditional house built about 2.5 meters tall, has one windowless door, with a thatched roof, wooden walls and grounded ground.

This Honai has a wood stove that aims to withstand the cold temperatures of Baliem valley is quite extreme that is 4.5 degrees Celsius to 24.5 degrees Celsius. The furnaces in Honai have fuels that come from wood or dried plants.

The indoor air pollution in wood stove includes combustion smoke used for cooking, lighting, body warmers and cigarette smoke. This material was burned and significantly release pollutant substances such as particulate matter (PM), carbon monoxide (CO), nitrogen oxides and polycyclic aromatic hydrocarbons. The concentration of this substance has even been found 10 or even 100 times higher than the maximum level recommended by the World Health Organization (WHO) guidelines (Heinzerling et al., 2016; Fullerton et al., 2008).

Papua women who traditionally do activities within the Honai and bring their children tend to have high exposure to biomass smoke. (Diette et al., 2012; Gordon et al., 2014).

Children who exposed during the critical period of lung development showed an increased risk of acute lower respiratory tract infections, oxidative stress from exposure to air pollutants, and asthma.
(Smith et al., 2011; Heinzerling et al., 2016).

Indoor air pollution affects alveolar macrophages (AM) in the lungs, alveolar macrophages regulate the prevention process of infection especially Streptococcus pneumoniae by activating NADPH oxidase that will kill the bacteria that cause pneumonia and trigger the release of cytokine enzymes that can prevent inflammation (Gordon et al., 2000; Xu et al., 2008; Rylance et al., 2015).

However, particles in wood smoke combustion will induce free radicals, activate macrophage $\mathrm{NF}-\kappa \mathrm{B}$, decrease intracellular glutebate exposure, strengthen TNFa, IL-6, and CXCL8 excretion. Both of these substances will be absorbed by lipopolysaccharide and increase the effects of inflammation in the lungs. (Leonard et al., 2000; Semple et al., 2010).

Exposure to acute burning particles will produce a pro-inflammatory effect, this has been increasing the cycle of CXCL8 and neutrophilia systemically because wood burning releases a lot of nitric oxide and malondialdehyde substances that cause the lungs to experience oxidative stress (Barregard et al., 2008).

Leung et al. (2016) has reported the areas where morbidity and mortality from pneumonia remain high have less access to clean water, less latrine, poor sanitation and low immunization status. Therefore, WHO creates a monitoring program aimed at preventing environmental contamination from the feces of an infected person to improve sanitation to be more hygienic by making connections to sewerage systems, septic tanks, flush toilets with ventilation and latrines with concrete slabs (Brown, Cairncross and Ensink, 2013).

The immunization of $\mathrm{M}$. bovis Bacille CalmetteGuérin (BCG) has been reported to have beneficial non-specific effects that 
may protect the baby from the effects of tuberculosis (TB) and other pulmonary diseases. A previous case-control study in Brazil showed BCG reduced the risk of death from pneumonia by $50 \%$ in children less than one year (Kleinnijenhuis et al., 2015).

Two immunologic mechanisms of BCG immunization to prevent pneumonia are the short-term effects of epigenetic programming from innate immune cells, a process called 'trained immunity', and longterm effects induce the effects of the nonspecific potency of innate immunity and Theterologic assistants at least one years after vaccination. (Triccas et al, 2016; Faustman et al., 2012).

The explanation for this process is 'cross-protection' or later referred to as 'heterologous immunity'. In this process, cross-protection is formed by lymphocytes that release IFN $\gamma$ after stimulation with the first pathogens and then activate bystander macrophages that enhance innate immunity to secondary infections (Kleinnijenhuis et al., 2015).

\section{REFERENCE}

Barregard L, Sallsten G, Almstrand AC, Gustafson P, Andersson M, Olin A (2008). Experimental exposure to wood smoke: effects on airway inflammation and oxidative stress, Occup Environ Med. 65(5): 319-324.

Brown J, Cairncross S, and Ensink J HJ. (2013). Water, sanitation, hygiene and enteric infections in children. Archives of Disease in Childhood. 98(8): 629-634.

Diette GB, Accinelli RA, Balmes JR, Buist AS, Checkley W, Garbe P, Hansel NN, et al. (2012). Obstructive lung disease and exposure to burning biomass fuel in the indoor environment. Global Heart. pp. $265-270$.
Faustman DL, Wang L, Okubo Y, Burger D, Ban L, Man G, Zheng H, et al. (2012). Proof-of-concept, randomized, controlled clinical trial of bacillus calmette-guerin for treatment of longterm type 1 diabetes. PLoS ONE, 7(8).

Fullerton DG, Bruce N, and Gordon SB. (2008). Indoor air pollution from biomass fuel smoke is a major health concern in the developing world. Transactions of the Royal Society of Tropical Medicine and Hygiene. pp. 843-851.

Gordon SB, Irving GRB, Lawson RA, Lee ME, Read RC. (2000) Intracellular trafficking and killing of Streptococcus pneumoniae by human alveolar macrophages are influenced by opsonins, Infection and Immunity. 68(4): pp. 2286-2293.

Gordon SB, Bruce NG, Grigg J, Hibber PL, Kurmi OP, Lam K, Hubert, Mortimer, Kevin. (2014) Respiratory risks from household air pollution in low and middle income countries. The Lancet Respiratory Medicine. pp. 823-86o.

Heinzerling AP, Guarnieri, Michael J, Mann JK, Diaz JV, Thompson LM. Diaz A, Bruce NG. et al. (2016). Lung function in woodsmoke-exposed Guatemalan children following a chimney stove intervention. Thorax, 71(5): 421-428.

Kementerian Kesehatan Republik Indonesia. (2012). Profil Data Kesehatan Indonesia Tahun 2011. Jakarta: Kementerian Kesehatan RI.

Kleinnijenhuis J, Quintin J, Preijers F, Benn CS, Joosten LAB, Jacobs C, Loenhout JV. et al. (2015). Longlasting effects of BCG vaccination on both heterologous Th1/Th17 responses and innate trained immunity. NIH Public Access. 6(2): pp. 152-158. Kliegman RM. (2016). Nelson TEXTBOOK 
of PEDIATRICS, Edition 17.

Leonard SS, Wang S, Shi X, Jordan BS, Castranova V, Dubick MA. (2000). Wood smoke particles generate free radicals and cause lipid peroxidation, DNA damage, NFkB activation and TNF- $\alpha$ release in macrophages. Toxicology. 150(1-3): 147-157.

Leung DT, Chisti MJ, and Pavia A T. (2016). Prevention and Control of Childhood Pneumonia and Diarrhea. Pediatric Clinics of North America: 67-79.

Rylance J, Fullerton DG, Scriven J, Aljurayyan AN, Mzinza D, Barrett S, Wright, Adam KA. et al. (2015). Household air pollution causes dosedependent inflammation and altered phagocytosis in human macrophages. American Journal of Respiratory Cell and Molecular Biology. 52(5): 584593.

Semple S, Devakumar D, Fullerton DG, Thorne PS, Metwali N, Costello A, Gordon SB, et al. (2010). Airborne endotoxin concentrations in homes burning biomass fuel. Environmental
Health Perspectives. 118(7): 988-991. Smith KR, McCracken JP, Weber MW, Hubbard A, Jenny A, Thompson LM, Balmes J, et al. (2011). Effect of reduction in household air pollution on childhood pneumonia in Guatemala (RESPIRE): A randomised controlled trial. The Lancet. 378 (9804): 1717-1726.

Triccas JA, Counoupas C (2016). Novel vaccination approaches to prevent tuberculosis in children. Pneumonia. 8(1): 18.

World Health Organization and The United Nations Children's Fund (2006). Pneumonia: The Forgotten Killer of Children. Geneva: World Health Organization, The United Nations Children's Fund (UNICEF)/World Health Organization (WHO).

Xu F, Droemann D, Rupp J, Shen H, Wu X, Goldmann T, Hippenstiel S. et al. (2008). Modulation of the inflammatory response to Streptococcus pneumoniae in a model of acute lung tissue infection. Am J Respir Cell Mol Biol. 39(5): 522-529. 